\title{
Information Technology Impact on Learning Process and Academic Achievement of Student
}

\author{
Nor Hasan Noorlailie Soewarno Isnalita \\ Faculty of Economics and Business, Airlangga University
}

Profile and corresponding author : Nor Hasan ${ }^{1}$ is a student of Master of Accounting, Faculty of Economics and Business, Airlangga University. Noorlailie Soewarno ${ }^{2}$ is a lecturer of Master of Accounting, Faculty of Economics and Business, Airlangga University. Isnalita ${ }^{3}$ is a lecturer of Master of Accounting, Faculty of Economics and Business, Airlangga University.

\section{Abstract}

This study aimed to obtain empirical evidence regarding the correlation of the use of information technology to the learning process (lectures) and its impact on student academic achievement. This study used path analysis or analysis that not only tested the direct influence of independent variable to the dependent variable, but also explained the presence or absence of indirect influence given by the independent variable through the intervening variable to the dependent variable. This study uses questionnaires media that are disseminated through electronic media. The statements contained in the questionnaire were measured using the Likert scale of 5 (five) points, then processed using Path Analysis, and interpreted. Total respondents in this study as many as 204 students of Master of Accounting who have been through the course of information technology management. The results of this study indicate that information technology influences student academic achievement and influences the learning process and has an impact on student academic achievement.

Keywords : Information Technology; Learning Process; Student Academic Achievement.

DOI: $10.7176 / \mathrm{IKM} / 9-7-01$

Publication date: August $31^{\text {st }} 2019$

\section{INTRODUCTION}

The use of information technology becomes an integral part of the learning procedure at the university. Some teaching staff have enthusiastically applied technological innovation as part of the learning process in the classroom. Nevertheless, the influence of information technology on student academic performance becomes quite a matter of debate (Bawaneh, 2011; Zoraini dkk, 2009).

Research on student academic performance is an important topic in the world of education. Factors that affect student academic performance are very important. These factors will greatly affect the university's academic policies, lecturer performance appraisals and modification of the way lecturers teach (Guney, 2009).

Bawaneh (2011) mentioned that before the computer is familiar in the community, the learning process is done traditionally. But in recent years along with the technological advances, the use of computers in the community is increasing. Increased use of information technology has a positive impact on the world of education, especially in the way and the process of delivering learning materials. Even the majority of universities in the United States have been doing online accounting perkualiahan with berorietasi on the use of websites and social media.

With reference to research researchers tried to develop the research by not only testing the powerpoint aspect as a learning medium but testing the use of information technology in general to student achievement. The development of computer technology has influenced rapidly to various joints of community life including in the process of learning at the University. Bawaneh (2011) states that information technology today can not be separated from the learning process in education. Various educational institutions from elementary school up to the University have been competing to invest in information technology as an effort to improve the quality of education. (Khan, 2009) explains that a large development in the field of information technology has a major impact on the role of educational institutions. Educational institutions vying to spend their financial resources to update the information technology. The development of information technology is expected to give a positive impact on the procedures of students in learning.

Carrillo dkk. (2011) states that improving the quality of education is the main objective of most developing countries. The rapid development of information technology has a significant impact on education. In the process of education, the use of IT is expected to improve student performance through several ways: first, the existence of information technology in the classroom is expected to improve the quality of the learning process that affects the performance of students; second, the use of IT is expected to improve students' cognitive abilities expected to have a positive impact on student academic performance. (Khan, 2009) revealed that the use of information technology is expected to have a positive impact on student learning. 


\section{LITERATURE REVIEW}

Compeau dan Higgins (1995) explained that the capabilities and expertise of a person's computer to perform tasks related to information technology computer self efficacy needed in a person in using information technology to utilize it in facilitating the process of learning and achieving maximum academic achievement.

Computer technology, communication technology, any technology is a media that can provide added value to the organization (Mustakini, 2009; Rauniar dkk, 2014). The growth of computer use provides great potential in developing the learning process. Internet, wireless, tablet computers and other IT developments provide revolutions in the way the University is learning (Frey dkk, 2009).

Jabr, (2011) and Kadous dan Magro (2001) tries to give an explanation of the internet usage of student achievement. The Internet provides flexibility for students to find and download the required course materials. The development of websites, blogs, emails, and social media to expand the communication network both between faculty and students and with fellow students. Internet use can have a positive impact on student achievement if directed well.

The implementation of lecturing process is an interaction between lecturers and students who are quite dominant. The process of interaction between lecturers and students is not solely dependent on the method or method used, but also the other components also affect the success in the interaction of teaching and learning. These components, among others: lecturers, students, methods, tools or technology, facilities, and lecture objectives (Sardiman, 2004 : 173). (Slameto, 2010) and (Iskandaryah, 2012) states that academic achievement is influenced by lecturing process. Learning activities are an educational process both at school and on campus. This means that the success or failure of the achievement of educational goals depends a lot on how the achievement of the taxonomy of education experienced by students covering congnitive, affective, and psychomotor aspects. In an educational institution the success of teaching and learning process can also be seen from the achievement of learning achieved by learners.

Nugraha (2015) said in the context of learning there are some benchmarks that can be used to determine learning achievement. One of the benchmarks used is the achievement of learning that refers to the achievement of the education taxonomy that covers aspects of cognitive, affective, and psychomotor. One of the efforts that make someone achievement is to carry out continuous activities. That is, after someone realizes his potential in a field then he will continue to strive to develop it into the main ability.

Information technology is able to prove its role in increasing student involvement by integrating learning tasks to achieve achievement with high learning outcomes (Kanapathippillai dkk., 2012; Yaftian dkk., 2017). Based on the description, it can be hypothesized as follows:

$\mathrm{H}_{1}$ : Information technology affects Student Achievement

Essentially an effective learning process occurs if the lecturer can change the ability and perception of students from difficult to learn something to be easy to learn. Effective learning and teaching processes depend largely on the selection and use of learning methods (Popham and Baker, 1992). (Pujasari and Nurdin, 2008) revealed that the competence of lecturers greatly determine student achievement. The higher the competence of educators, then the chances of learners get good learning outcomes.

Factors that can affect student's learning achievement include teaching style of lecturer, assistance to students, lecture structure, and teaching and learning facilities. Students will better understand the courses being pursued if at the time of teaching lecturers do not press, and in accordance with the syllabus / SAP has been agreed. Lecturers not only have academic ability in certain subjects, but also must have the ability to teach in the class well, such as the establishment of appropriate methods for teaching, maintaining a conducive atmosphere in the classroom, and willing to conduct two-way discussion in order to establish good communications between both parties . A good learning process will also be able to have a significant impact on the academic achievement of learners (Iskandaryah, 2012).

Some universities used professional accountants to teach Information Technology to students and try to integrate it with courses, while other universities use Information Technology or the Department of Computer Science to teach accountants of information technology principles (Noor and Wan, 2016; Wessels, 2004). Learning achievement is influenced by internal and external conditions in the learning process. Internal conditions include physical conditions, psychological conditions and social conditions while external conditions include the existing environment in the learning and learning process (Anni, $2004: 14$ ).

Learning environment in the learning process was a factor that from outside the student self that can not be ignored just because the campus environment is often viewed with one eye as a factor that also affects the learning achievement although the impact caused indirectly to improve learning achievement. Campus environment as a place of learning process has the same meaning as the educational environment. The educational environment is all external conditions and influences on educational activities which are also the setting of the place of education (teaching and learning process) (Ettinger dkk, 2006; Hadi, 1996; Tirtarahardja dan La Sulo, 1994).

Adjani dan Adam (2013) also concluded in his research that the factors of learning motivation and process 
(experience) of learning have a significant influence on student academic achievement. Slameto (2010) and Nugraha (2015) states that academic achievement is influenced by learning habits and learning habits will affect learning itself. Sukmadinata (2005), Nugraha (2015), dan Turner dkk. (1998) reveals that learning achievement is the result of students' potential abilities that can be seen from the behaviors in the form of knowledge gained through learning, thinking skills, and motor skills. Thus, the mastery of students' knowledge of a particular subject can be seen from the achievement or learning outcomes through the test of learning achievement / exam semester.

Information technology is believed to give a significant influence on teaching and learning process as well as impact on student academic achievement, therefore can be hypothesized as follows:

H2: Information technology influences Learning Process and affects Student Achievement

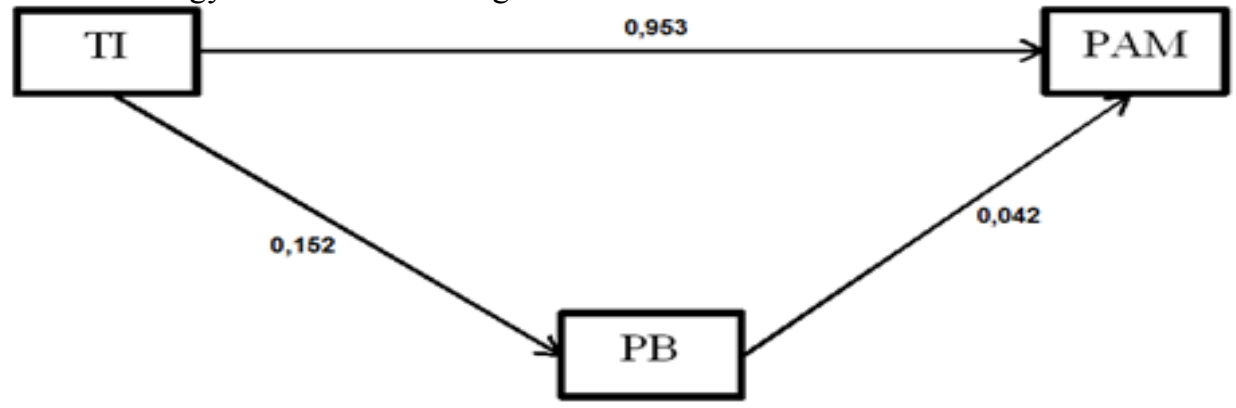

Gambar 1. Desain Penelitian

\section{RESEARCH METHOD}

This study examined the impact of the use of information technology on student academic achievement by raising the lecture or learning process as moderation. This study uses questionnaires media that were disseminated through electronic media. The statements contained in the questionnaire were measured using the Likert scale of 5 (five) points, then processed used Path Analysis, and interpreted and supported by previous studies that have been done by researchers. Total respondents in this study were 204 students.

The use of information technology (X) in this study was measured by 10 (ten) statements, namely: (1) I can well use microsoft word application; (2) I can well use microsoft excel application; (3) I can well use microsoft power point application; (4) I can use the internet well; (5) I can search for additional course material from internet; (6) The Internet helps me in learning; (7) The Internet makes it easy for me to share college information with friends; (8) Lecturer uses technology in lecturing process; (9) The use of IT in the perquest process makes me more aware of the material presented; and (10) IT use makes me more interested in learning.

The learning process (Y) in this study was measured by 9 (nine) statements, namely: (1) The lecturer convey the purpose (benefit) of the lecture; (2) The lecturer shall deliver the lecture contract at the beginning of the lecture; (3) The lecturer uses the latest reference book and literature (last 5 years); (4) Lecturer completes lectures with teaching materials / diktat / handout; (5) The lecturer starts and ends the lecture on time according to the schedule specified; (6) Conformity between material submitted by lecturer and planning in lecture contract; (7) Submission of lecture materials by lecturers; (8) The lecturer gives examples of real (illustrative) applications related to lecture material; and (9) Lecturer's ability to integrate the use of technology media in learning.

Winkel (1989) states that academic achievement is one proof that shows the ability or success of someone who did the learning process in accordance with the weight or value he achieved. Therefore, the academic achievement of students $(Z)$ in this study is measured from the final score (the result of midterm examination plus the final exam result of the semester) students who have gone through the course of information technology management.

\section{RESULTS AND DISCUSSION}

Path analysis or path analysis not only examines the direct influence of independent variables on the dependent variable, but also explained the presence or absence of indirect influence given the independent variable through the intervening variable to the dependent variable. The influence of independent variables on the intervening variable can be seen from the test result of regression $t$ value as presented in table 1 below:

Table 1. Value of t Regression

\begin{tabular}{|c|c|c|c|c|c|c|}
\hline \multirow{2}{*}{\multicolumn{2}{|c|}{ Model }} & \multicolumn{2}{|c|}{ Unstandardized Coefficients } & \multirow{2}{*}{\begin{tabular}{|l|} 
Standardized Coefficients \\
Beta \\
\end{tabular}} & \multirow[b]{2}{*}{$t$} & \multirow{2}{*}{ Sig. } \\
\hline & & $\mathrm{B}$ & Std. Error & & & \\
\hline \multirow{2}{*}{1} & (Constant) & 25,748 & 3,370 & & 7,640 &, 000 \\
\hline & TIx & , 169 &, 077 &, 152 & 2,190 &, 030 \\
\hline
\end{tabular}

Source: Processed data 
Based on table 1 it could be seen that the significance value of 0.03 is smaller than 0.05 . This proves that there is significant influence of independent variable to intervening variable. While the direct influence of the independent variable to the dependent variable and indirect influence of independent variables through intervening variable to the dependent variable can be known from the test result of $t$ regression as presented in table 2 below:

Table 2. Value of t Regression

\begin{tabular}{|l|l|l|l|l|l|r|}
\hline \multirow{2}{*}{ Model } & \multicolumn{2}{|l|}{ Unstandardized Coefficients } & Standardized Coefficients & \multirow{2}{*}{$\mathrm{t}$} & \multirow{2}{*}{ Sig. } \\
\cline { 2 - 9 } & B & Std. Error & Beta & & 2,691 &, 008 \\
\hline \multirow{4}{*}{1} & (Constant) & 4,504 & 1,674 &, 953 & 48,037 &, 000 \\
\cline { 2 - 9 } & TIx & 1,641 &, 034 &, 042 & 2,097 &, 037 \\
\cline { 2 - 9 } & PBy &, 065 &, 031 & &
\end{tabular}

Source: Processed data

Based on table 2 it clearly showed that the significance value of 2 (two) variables, namely $\mathrm{X}=0.00$ and $\mathrm{Y}=$ 0.037 which are both smaller than 0.05 . These results give the conclusion that the variables $\mathrm{X}$ and $\mathrm{Y}$ have a significant effect on the variable $\mathrm{Z}$.

From both tables $t$ regression value above could be seen that the direct effect given $X$ against $Z$ of 0.953 . While the indirect effect of $\mathrm{X}$ through $\mathrm{Y}$ to $\mathrm{Z}$ is the result of multiplication between beta value $\mathrm{X}$ to $\mathrm{Y}$ with beta value $\mathrm{Y}$ to $\mathrm{Z}$, that is: $0,152 \times 0,042=0,006$. Then the total effect given by $\mathrm{X}$ to $\mathrm{Z}$ is the direct influence coupled with the indirect influence that is: $0.953+0.006=0.959$. Based on the calculation results can be seen that the value of direct influence $\mathrm{X}$ to $\mathrm{Z}$ of 0.953 and the influence of $\mathrm{X}$ indirectly to $\mathrm{Z}$ of 0.959 which means that the value of indirect effect $X$ to $Z$ greater than the value of direct influence. These results indicate that indirectly $X$ through $\mathrm{Y}$ has a significant influence on $\mathrm{Z}$.

From the description above, then the second hypothesis, namely information technology influence on Learning Process and impact on Student Academic Achievement, could be accepted. The direct influence of the use of information technology on student academic achievement in accordance with research Ahadiat (2005), Kanapathippillai dkk. (2012) and Yaftian dkk. (2017) in a compact information technology able to prove its role in increasing the involvement of students by integrating learning tasks to achieve achievement with high learning outcomes. Information technology becomes a good media to improve student academic achievement. Information technology makes it easier for students to obtain the required information (Bowling, 2015; Vasarhelyi dan Romero, 2014). The use of information technology in the lecture process can have a positive impact on student achievement (Alves, 2010; Bawaneh, 2011; Beaubien, 2013; Svendsen and Mondahl, 2013; Horzum dkk., 2014;).

Technology had a good effect on the smoothness of the teaching and learning process, such as in shortening the time of completion of a job or task. By using technology, distance becomes not a barrier in communicating. The use of technology has an impact on the environment ie, reducing paperless use, thus maximizing the use of electronic files (softfile), especially in bookkeeping (Simarmata, 2015).

Academic achievement was influenced by lecturing process. Learning activities are an educational process both at school and on campus. This means that the success or failure of the achievement of educational goals depends a lot on how the achievement of the taxonomy of education experienced by students covering congnitive, affective, and psychomotor aspects. In an educational institution the success of teaching and learning process can also be seen from the achievement of learning achieved by learners (Slameto, 2010).

\section{CONCLUSION AND LIMITATIONS}

This study aimed to obtain empirical evidence regarding the correlation of the use of information technology to the learning process (lectures) and its impact on student academic achievement. Based on the empirical results and discussion as mentioned above, this study yields two conclusions, namely: First. The use of information technology could give a significant influence on student achievement. The use of technology provides flexibility for students to search for data and information and to download the required lecture material. The development of websites, blogs, emails, and social media to expand the network of communication between lecturers and students with fellow students. The use of technology can have a positive impact on student achievement if directed properly and correctly (Lai dkk., 2008; Jabr, 2011; Fraser, 2013; Bakhsh dkk., 2017).

Second. Information technology affects the learning process and affects the students' academic achievement. The second conclusion gave a more significant value than the first conclusion. That is, technology will give a significant impact on student academic achievement if the technology is also used in the learning process or lectures. Factors of learning motivation and process (experience) of learning have a significant influence on student achievement. Academic achievement is influenced by learning habits and learning habits will affect learning itself (Adjani dan Adam, 2013; Slameto, 2010).

The amount of respondents as many as 204 students were only collected from one university, the University of Airlangga, which may limit the strength of research results. Airlangga University also has a uniqueness as a 
State University of Legal Entity (PTN BH) which has a different system with other universities. Therefore, the results may not be generalizable to other Universities with different systems. Subsequent research is suggested to expand the study sample and test other variables that are suspected to have an effect on academic achievement.

\section{REFERENCE}

A. M. Sardiman. (2004). Interaksi dan Motivasi Belajar Mengajar. Jakarta: Raja Grafindo Persada.

Adjani Sagita dan Helmy Adam. (2013). FAKTOR-FAKTOR YANG MEMPENGARUHI PRESTASI BELAJAR MAHASISWA PADA MATA KULIAH PENGANTAR AKUNTANSI. Jurnal Ilmiah Mahasiswa FEB, 1(1).

Ahadiat, N. (2005). Factors that may influence or hinder use of instructional technology among accounting faculty. Campus-Wide Information Systems, 22(4), 210-232. https://doi.org/10.1108/10650740510617520

Alves, M. D. C. F. G. (2010). Management accounting and information technology - Some empirical evidence. In Studies in Managerial and Financial Accounting (Vol. 20). https://doi.org/10.1108/S14793512(2010)0000020018

Bakhsh, M., Mahmood, A., \& Sangi, N. A. (2017). Examination of factors influencing students and faculty behavior towards m-learning acceptance: An empirical study. International Journal of Information and Learning Technology, 34(3), 166-188. https://doi.org/10.1108/IJILT-08-2016-0028

Bawaneh, S. S. (2011). Does using computer technology improve students ' performance ? Evidence from a management accounting course. Journal of Business, 2(10), 266-275.

Beaubien, L. (2013). Technology, change, and management control: A temporal perspective. Accounting, Auditing and Accountability Journal, 26(1), 48-74. https://doi.org/10.1108/09513571311285612

Bowling, C. (2015). Audit Support System Use: Appropriate The Influence of Auditor, Audit Team, and Firm Factors. 84(3), 771-810.

Carrillo, P. E., Onofa, M., \& Ponce, J. (2011). Information Technology and Student Achievement: Evidence from a Randomized Experiment in Ecuador. Ssrn, (December). https://doi.org/10.2139/ssrn.1818756

Catharina Tri Anni. (2004). Psikologi Belajar. Semarang: UPT Unnes Press.

Compeau, B. D. R., \& Higgins, C. A. (1995). Development of a Measure and Initial Test Background-Social. 19(2), 189-211.

Ettinger, A., Holton, V., \& Blass, E. (2006). E-learner experiences: What is the future for e-learning? Industrial and Commercial Training, 38(4), 208-212. https://doi.org/10.1108/00197850610671991

Frey S., B., Savage A., D., \& Torgler, B. (2009). Surviving the Titantic Disaster: Economic, Natural and Social Determinants.

Guney, Y. (2009). Exogenous and endogenous factors influencing students' performance in undergraduate accounting modules. Accounting Education, 18(1), 51-73. https://doi.org/10.1080/09639280701740142

Hadi Kusumo. (1996). Pengantar Pendidikan. Semarang: IKIP Semarang Press.

Horzum, M. B., Öztürk, E., Bektaş, M., Güngören, Ö. C., \& Çakir, Ö. (2014). Secondary school students tablet computer acceptance and readiness: A structural equation modeling. Egitim ve Bilim, 39(176), 81-94. https://doi.org/10.15390/EB.2014.3500

Iskandaryah, D. dan I. G. (2012). Analisis Faktor yang Memengaruhi Prestasi Mahasiswa dalam Mempelajari Mata Kuliah Akuntansi Keuangan Menengah, Studi Empiris pada Mahasiswa Jurusan Akuntansi Reguler di Fakultas Ekonomika dan Bisnis Universitas Diponegoro tahun angkatan 2009 dan 2010. Diponegoro Journal of Accounting, 1(2010), 1-13.

Jabr, N. H. (2011). Social Networking as a Tool for Student and Teacher Learning. International Journal of Business and Social Science, 2(12), 85-86.

Kadous, K., \& Magro, A. M. (2001). The Effects of Exposure to Practice Risk on Tax Professionals' Judgements and Recommendations. Contemporary Accounting Research, 18(3), 451-475. https://doi.org/10.1506/TF76-653L-R36N-13YP

Kanapathippillai, S., Shamlee Hasheem, A., \& Dellaportas, S. (2012). The impact of a computerised consolidation accounting package (CCAP) on student performance. Asian Review of Accounting, 20(1), 419. https://doi.org/10.1108/13217341211224691

Khan, M. (2009). Effects of Information Technology Usage on Student Learning - An Empirical Study in the United States. International Journal of Management, 26, 354.

Lai, M., Lai, M., Lin, J. C., Chang, H., Wessels, P. L., Gombachika, H. S. H., \& Khangamwa, G. (2008). Campus-Wide Information Systems Article information :

Lisbet Pals Svendsen and Margrethe Smedegaard Mondahl. (2013). How social-media enhanced learning platforms support students in taking responsibility. Journal of Applied Research in Higher Education, 5(2), 261-272.

Melissa T. A. Simarmata. (2015). Model Penerimaan Teknologi (Technology Acceptance Model). Medan: Universitas HKBP Nommensen. 
Michael Fraser. (2013). "Fleshing out" an engagement with a social accounting technology. Accounting, Auditing \& Accountability Journal, 25(3), 508-534.

Mustakini. (2009). Sistem Informasi Teknologi. Yogyakarta: Andi Offset.

Nana Syaodih Sukmadinata. (2005). Landasan Psikologis Proses Pendidikan. Bandung: PT Remaja Rosdakarya.

Noor, W., \& Wan, H. (2016). iMindMap as an innovative tool in teaching and learning accounting: an exploratory study. https://doi.org/10.1108/ITSE-05-2015-0012

Nugraha, M. L. (2015). Pengaruh Persistensi Diri dan Kebiasaan Belajar terhadap Kemampuan Pemecahan Masalah Matematika Di SMP Swasta Jakarta Timur. Research and Development Journal Of Education, 2(1), 12-19.

P.L. Wessels. (2004). Information technology and the education of professional accountants. Meditari Accountancy Research, 12(1), 219-234. https://doi.org/10.1108/MEDAR-02-2014-0029

Rauniar, R., Rawski, G., Yang, J., \& Johnson, B. (2014). Technology acceptance model (TAM) and social media usage: An empirical study on Facebook. Journal of Enterprise Information Management, 27(1), 6-30. https://doi.org/10.1108/JEIM-04-2012-0011

Slameto. (2010). Belajar dan Faktor- Faktor yang Mempengaruhinya. Jakarta: Rineka Cipta.

Turner, J. L., Smith, M., \& Gurd, B. (1998). Auditing income tax self-assessment: The hidden cost of compliance. Managerial Auditing Journal, 13(2), 95-100. https://doi.org/10.1108/02686909810202782

Umar Tirtarahardja dan La Sulo. (1994). Pengantar pendidikan. Jakarta: Proyek Pembinaan dan Peningkatan Mutu Tenaga Kependidikan. Dikti.

Vasarhelyi, M. A., \& Romero, S. (2014). Technology in audit engagements: A case study. Managerial Auditing Journal, 29(4), 350-365. https://doi.org/10.1108/MAJ-06-2013-0881

W. James Popham Eva L. Baker. (1992). Teknik Mengajar Secara Sistematis. Jakarta: PT. Rineka Cipta.

W. S. Winkel. (1989). Psikologi Pengajaran. Jakarta: PT. Gramedia Widia Sarana Indonesia.

Yaftian, A., Mirshekary, S., \& Mihret, D. G. (2017). Learning commercial computerised accounting programmes Perceptions and motivations. Accounting Research Journal, 30(3), 312-332. https://doi.org/10.1108/ARJ08-2015-0107

Yayah Pujasari dan Nurdin. (2008). PENGARUH KOMPETENSI PROFESIONAL GURU TERHADAP KEBERHASILAN BELAJAR SISWA. Jurnal Administrasi Pendidikan, 8, 2. Retrieved from http://ejournal.upi.edu/index.php/JAPSPs/article/view/6297

Zoraini Wati Abas, Chng Loi Peng, M. N. (2009). A Study On Learner Readiness For Mobile Learning At Open University Malaysia. IADIS International Conference Mobile Learning, (978-972-8924-77-5). 